\title{
УДК (UDC) 691.32 \\ STUDY ON COMPRESSIVE STRENGTH OF PLASTIC WASTE BITUMINOUS CONCRETE FOR ROAD CONSTRUCTION
}

\section{ИССЛЕДОВАНИЕ ПРОЧНОСТИ НА СЖАТИЕ БИТУМИНОЗНОГО БЕТОНА С ДОБАВКАМИ ПЛАСТМАССОВЫХ ОТХОДОВ ДЛЯ ДОРОЖНОГО СТРОИТЕЛЬСТВА}

\author{
Anurag V. Tiwari ${ }^{1}$, Dr. Y R M Rao ${ }^{2}$ \\ Тивари А.В. ${ }^{1}$, Рао Дж.Р.М. ${ }^{2}$ \\ 1 - Sipna College of Engineering and Technology (Amravati (M.S), India) \\ 2 - Dr. Pauls Engineering College (Villupuram Dist (T.N), India)
}

\begin{abstract}
Аннотация. Промышленность производства пластмассовых изделий за последние два десятилетия претерпела много важных изменений в результате более широкого использования пластмасс в различных отраслях экономики. Одним из наиболее используемых пластмассовых изделий являются тонкие полиэтиленовые пакеты, используемые для упаковки. Утилизация отходов полиэтиленовых пакетов в больших количествах представляет собой реальную экологическую проблему. Таким образом, переработка отходов в полезные продукты рассматривается как один из наиболее распространенных решений этой проблемы, поэтому исследования в области новых и инновационных видов использования отходов постоянно расширяются. В данной работе изучается прочность на сжатие битуминозного бетона с добавками пластиковых отходов для дорожного строительства. Пластиковые отходы добавлялись в битуминозный бетон в различном проиентном соотношении и готовились образиь Маршалла. Эти образиь были испьттаны на прочность при сжатии при $25^{\circ} \mathrm{C}$ и $60^{\circ} \mathrm{C}$. Прочность образиа на сжатие значительно возрастает - до 8\%, $6 \%$ и 12\% для сухого проиесса, мокрого процесса $и$ комбинированного прочесса соответственно для отходов пластмасс типа ПЭНД и ПЭВД.
\end{abstract}

Ключевые слова: дорожное строчтельство, битуминозный бетон, пластичные отходы, прочность на сжатие.

Дата принятия к публикации:

24.08 .2018 Дата публикации:

\section{Сведения об авторах:}

Тивари, Анураг Вирендра - доцент кафедры «Гражданское строительство» Колледжа техники и технологии Sipna (г. Амравати, штат Махараштра, Индия), anuragearth@gmail.com.

Pао Дж.P.М. - директор Инженерного колледжа д-ра Паулса (г. Виллупурам, штат Тамилнад, Индия),dryrmrao@rediffmail.com.
Abstract. Plastics industry have many major developments in the last two decades resulted from the increased utilization of plastics in various sectors. One of the most common used plastics is the thin plastic bags which used usually for packaging. However the disposal of the waste plastic bags in large quantities constitutes a real environmental problem. Hence, recycling waste into useful products is considered one of the most sustainable solutions to this crisis so that research into new and innovative uses of waste materials is continuously advancing. This paper studies the Compressive Strength of Plastic Waste Bituminous Concrete for Road Construction. The plastic waste was added to the bituminous concrete in increasing percentage and Marshall Samples were prepared. These samples were tested for compressive strength at $25^{\circ} \mathrm{C}$ and $60^{\circ} \mathrm{C}$ i.e unconditioned and conditioned samples. It is observed that the compressive strength of sample significantly increases up to $8 \%, 6 \%$ and $12 \%$ for dry process, wet process and combined process respectively for LDPE and HDPE type of waste plastic.

Keywords: road construction, bituminous concrete, plastic waste, compressive strength

Date of acceptance for publication: $\quad 24.08 .2018$

Date of publication: 25.09 .2018

\section{Authors' information:}

Anurag V. Tiwari - Assistant Professor, Department of Civil Engineering, Sipna College of Engineering and Technology, Amravati (M.S), India,

anuragearth@gmail.com.

Dr. Y R M Rao - Principal, Dr. Pauls Engineering College, Villupuram Dist (T.N), India,

dryrmrao@rediffmail.com. 


\section{Introduction.}

In the recent years rapid industrialization and large scale infrastructural development in India, has resulted in huge scarcity of construction materials and tremendous increase in the generation of waste products. Disposal of the waste products is a big challenge for the environmental engineers. Plastic waste is the most unwanted land waste all over the World. Some of these materials are non-biodegradable and often leads to waste disposal crisis and environmental pollution [1]. Use of this non-biodegradable (according to recent studies, plastics can stay as long as 4500 years on Earth) product is growing rapidly, and the problem is what to do with plastic-waste [2]. Scientists and engineers are constantly searching on different methods to improve the performance of asphalt pavements. Considerable research has been carried out to determine the suitability of plastic waste modifier in construction of bituminous mixes [3].

\section{Literature Review.}

Dr. Hamed M. Jassim and et.al (2014) studied optimum use of plastic waste to enhance the marshall properties and moisture resistance of hot mix asphalt. The plastic waste derived from the different types and sizes of bottles can be utilized to modify the asphalt mixture performance if added to aggregate with a specific (size, thickness and content). On the basis of experimental results, it was concluded that adding plastic waste with fine particles size ,thin thickness and at $15 \%$ by weight of total aggregate resulted in improving the Marshall stability and resistance to water damage, as well as they can contribute to relieve some of the environmental problems caused by classical plastic waste disposal means. The use of recycled plastic, in the manufacturing of hot asphalt mixture indicated to reduced permanent deformation in the form of rutting and reduced low-temperature cracking of the pavement surfacing. The field tests withstood the stress and proved that plastic wastes used after proper processing as an additive would enhance the life of the roads and also solve environmental problems.

Faris M. J. Najjar (2014) studied the effect of using dust on HMA properties. This paper presents a laboratory investigation about the effects of crushed boulders dust compared to ref- erence filler (limestone dust) on some properties of HMA mixture. The experimental work in this study provides a comparison among two filler types here we used dust of crushed boulders, and Limestone as fillers. Marshall Specimens are used to determine the Index of retained strength, compressive strength, stability, plastic flow, and indirect tensile strength. These specimens are prepared in accordance with the requirements of ASTM D-1559(Specimen dimensions, $\mathrm{D}=100.16, \mathrm{H}=63.5 \mathrm{~mm})$. The Hot Mixes Asphalt (HMA) has been prepared with equivalent design criteria. The use of crushed boulder dust over limestone dust gives more marshall stiffness value, increases the resistance to moisture damage by $135 \%$ than that of lime stone dust mix . Crushed dust gives highest compressive test than the mixture of crushed dust and limestone dust and has higher indirect tensile stiffening values and is more beneficial economically and easy to produce and handle.

Bulgis and et.al. (2017) studied effect of Buton Granular Asphalt (BGA) on compressive stress- strain behavior of asphalt emulsion mixture. The purpose of this study is to replace the petroleum bitumen with local materials such as natural rock asphalt. BGA used has a relatively uniform grain size with a maximum size of 1.18 $\mathrm{mm}$. Utilization of bitumen emulsion in production of cold mix asphalt mixture is an effective technology for decreasing the energy consumption. Test results revealed that utilizing 2.5\% BGA in asphalt emulsion mixture gives improved compressive strength. Furthermore, mixture with BGA has less crack number as compared with the mixture without BGA. Hence, extracted bitumen of BGA can be combined with petroleum bitumen within cold asphalt mixture to create higher binding capacity as compared to cold asphalt mixture without BGA.

Bindu and et.al (2015) studied Influence of natural fibres on the compressive strength of Stone Matrix Asphalt mixtures. This paper focuses on the influence of additives like coir, sisal, banana fibres (natural fibres), on the compressive strength of SMA mixtures. Compressive strength tests are conducted to study the resistance to crushing to withstand the stresses due to traffic loads. SMA is a gap graded bituminous mixture containing a high proportion of 
coarse aggregates of sizes $20 \mathrm{~mm}, 10 \mathrm{~mm}$ and stone dust and filler with relatively less medium sized aggregates. Additives enhance the resistance to moisture susceptibility of the mixture. Presence of additives strengthen the bonding between the aggregates provided by the binder and thereby enhancing the stone to stone contact which will result in increasing the resistance to crushing. This gives rise to a stiffer and tougher mix with considerable improvement in compressive strength.

Firdus Chairuddin and et.al (2016) studied the Compressive Strength of Permeable Asphalt Pavement Using Domato Stone (Quarzite Dolomite) and Buton Natural Asphalt (BNA) Blend.

Buton Natural Asphalt (BNA) blend is a type of modification asphalt which is made of $75 \%$ Petroleum asphalt $60 / 70$ and $25 \%$ rock asphalt Buton Natural extraction. The unconfined compressive test result of porous asphalt containing domato stone showed that the mixture with 4\% BNA has compressive strength value $2.4 \mathrm{MPa}$. This work is a part of various extensive investigation projects on the development of liquid Asbuton as bituminous asphalt binder and the suitability of domato stone as coarse aggregate in the permeable asphalt production. The results of porosity test, permeability test, stability test, flow test, indirect tensile test and material loss test (Cantabro test) showed the bonding strength between BNA blend and domato stones can be established and thus enhance the resistance of porous asphalt against raveling, rutting and shoving.

Agrawal H. S. and et.al (2017) studied the utilisation of plastic waste in flexible pavement design. Plastic which seems to be a cheaper and effective raw material on the other hand is very hazardous to the environment because of its non- degradable nature. Therefore it becomes essential to utilize waste effectively with technical innovations. Plastic can be utilized as a partial blending material in design of flexible pavement and also as a partial replacement in bitumen as well as coating over aggregate. Addition of plastic in bitumen improves the stability, strength, life and other desirable properties of bitumen utilization of waste plastic in the construction of pavement has shown better re- sistance to water which reduces the stripping of bitumen from aggregate and also made investigations over the use of waste plastic in road construction as an effective way to reutilize the plastic waste. According to various tests conducted, plastic as a $10 \%$ replacement in bitumen can give better result in flexible pavement design. Addition of plastic shows increase in compressive strength, tensile strength and stability value which is useful to sustain large load

Mustafa Tuncan and et.al (2003) studied the use of waste materials in asphalt concrete mixtures. The use of industrial wastes as additives in asphalt mixtures is the key concept of this experiment. Industrial wastes such as plastic, rubber, fly ash, marble powder and petroleum contaminated soil (PCS) were used as filler materials to prepare asphalt concrete mixtures. They are incorporated in asphalt mixtures to enhance the properties and performance of asphalt concrete pavements. Addition of crumb rubber to hot-mix asphalt concrete was observed to improve rheological properties of the asphalt such as viscosity, softening point, penetration, temperature susceptibility, strength and durability. Pavements made of rubber and plastic modified asphalt concrete have better skid resistance, less cracking and a longer pavement life in comparison to conventional asphalt pavements.

Abdul Gaus and et.al (2015) studied the compressive strength of asphalt concrete binder course mixture using buton granular asphalt (BGA). This study aims to evaluate the compressive stress-strain relationship of asphalt concrete mixtures using Buton granular asphalt (BGA) as partial replacement for petroleum asphalt in asphalt concrete bearing course (AC$\mathrm{BC})$ mixture production. Buton granural asphalt (BGA) is produced by crushing the natural rock asphalt to the maximum size of $1.16 \mathrm{~mm}$ which is homogenized. Asphalt concrete bearing course $(\mathrm{AC}-\mathrm{BC})$ is designed for a layer that can bear the traffic load. BGA alone is not enough for the purpose of mixing to have proper asphalt mixture therefore BGA have to be used with petroleum bitumen. The application of BGA as partially replaced petroleum asphalt in the (AC$\mathrm{BC})$ mixture improved the compressive strength and elastic modulus in comparison to (AC-BC) mixture without BGA. 
A.V. Tiwari et. al (2017) stated that waste plastic is accumulated all over the world causing serious environmental problems. They study the addition of plastic waste in bituminous concrete using dry process of mixing for road construction. The study evaluates the addition of shredded waste plastic in the bituminous concrete which results in significant increase in the stability value and Marshall Properties of mix. The study reveals that the use of waste plastic in bituminous concrete is safe and sustainable for road construction. The experiment was conducted into two phases. The first phase consists of calculating the optimum value of the bitumen and second phase consists of optimizing the quantity of plastic waste used to replace the bitumen. Dry process was used to prepare Marshall Samples. In this process the coarse aggregates and fine aggregate and fly ash were heated to $170^{\circ} \mathrm{C}$. The shredded plastic waste retaining on $2.36 \mathrm{~mm}$ sieve is added in proportion by weight to the hot aggregate. The waste plastic LDPE, PVC and HDPE was added varying from $0 \%, 2 \%, 4 \%, 6 \%, 8 \%, 10 \%$ and $12 \%$ by the weight of bitumen. This plastic gets coated over the aggregate uniformly. Immediately the hot Bitumen at $160^{\circ} \mathrm{C}$ is added to the mixture. After proper mixing the mix was placed in the compaction mould and compacted with 75 blows on both face to get Marshall Samples. The stability and flow were obtained by testing the sample on the digital Marshall frame and the average values for Bulk specific Gravity, AV, VMA and VFB were calculated and graphs were plotted. The values obtained stability values are corrected after applying the correction for thickness of the sample. From the study it can be concluded that addition of plastic improves the Marshall properties of the mix. The Addition of $8 \%$ of the LDPE and HDPE plastic waste improves the stability value of the bituminous mix which results is the increase in the toughness of the mix. The roads can withstand heavy traffic and shows better service life.

According to A.V Tiwari et. al (2017) the major portion of highway in India is flexible. Recent research suggests that these plastic materials can be used in road construction as a binding material. Polyethylene is extensively used plastic material, and it has been found to be one of the most effective polymer additives in road construction. From the investigation on utility of plastic waste as an additive for bituminous concrete using wet process of mixing it can be concluded that addition of plastic improves the Marshall properties of the mix. The Addition of $6 \%$ of the LDPE and HDPE plastic waste improves the stability value of the bituminous mix which results is the increase in the toughness of the mix. The roads can withstand heavy traffic and shows better service life. Due to addition of plastic waste the flow value increases resulting the improvement in the workability. Addition of plastic waste results in decrease in the air voids which reduces the bleeding of bitumen. The volumetric and Marshall properties of the mix show the acceptable trends and could satisfy the specified limits.

\section{Materials and Methods.}

Various materials used in the present study are bitumen, aggregate (fine and coarse), filler, and shredded plastic waste. The bitumen used for present study is of 60/70 penetration grade and is obtained from BPCL, Nagpur and PWD, Amravati. Coarse aggregates, fine aggregates and fly ash were collected from local producer of crushed aggregates. The plastic waste was segregated from the municipal waste and shredded at the local plastic waste recycling plant at MIDC, Amravati. Table 1 and Table 2 shows the physical properties of the aggregates and bitumen respectively.

Sieve analysis test was used to determine the aggregate sizes. Through this sieve test, the proportion of coarse aggregates, fines aggregate and filler was determined and ensuring the aggregate were well blended within the gradation limit as specified in MORTH shown in Table 3.

The experiment was conducted using three different processes of mixing waste plastic into bituminous concrete viz. Dry process, wet process and combined process. In Dry process the coarse aggregates and fine aggregate and fly ash were heated to $170^{\circ} \mathrm{C}$. The shredded plastic waste retaining on $2.36 \mathrm{~mm}$ sieve is added in proportion by weight to the hot aggregate. The waste plastic LDPE, PVC and HDPE was added varying from $0 \%, 2 \%, 4 \%, 6 \%, 8 \%, 10 \%$ and $12 \%$ by the weight of bitumen. This plastic gets coated over the aggregate uniformly. Immedia- 
Physical Properties of Coarse Aggregates

\begin{tabular}{|c|l|c|c|c|c|}
\hline $\begin{array}{c}\text { Sr. } \\
\text { no }\end{array}$ & \multicolumn{1}{|c|}{ Parameter } & $\begin{array}{c}\text { No. of tests } \\
\text { Performed }\end{array}$ & Test Result & $\begin{array}{c}\text { Specification } \\
\text { Requirement }\end{array}$ & Standard \\
\hline 1 & Impact value & 3 & $22.40 \%$ & Max 30\% & IS : 2386 (Part IV) - 1963 \\
\hline 2 & Abrasion value & 3 & $28.10 \%$ & Max 40\% & IS : 2386 (Part IV) - 1963 \\
\hline 3 & Crushing value & 3 & $24.30 \%$ & Max 30\% & IS : 2386 (Part IV) - 1963 \\
\hline 4 & $\begin{array}{l}\text { Combined Elongation } \\
\text { index and Flakiness } \\
\text { index }\end{array}$ & 3 & $17.20 \%$ & Max 30\% & IS : 2386 (Part I) - 1963 \\
\hline 5 & Specific gravity & 6 & $\begin{array}{c}20 \mathrm{mm:} 2.830 \\
\mathrm{~kg} / \mathrm{m}^{3} \\
10 \mathrm{mm:} 2.792 \\
\mathrm{~kg} / \mathrm{m}^{3}\end{array}$ & - & IS : 2386 (Part IV) - 1963 \\
\hline 6 & Water Absorption & 3 & $0.1 \%$ & Max 2\% & IS: 2386 (Part III)-1963 \\
\hline
\end{tabular}

Table 2

Physical Properties of Bitumen

\begin{tabular}{|c|l|c|c|c|}
\hline Sr. no & \multicolumn{1}{|c|}{ Parameter } & Test Result & Specification Requirement & Standard \\
\hline 1 & Penetration & 68 & $65-90$ & IS : 1203-1978 \\
\hline 2 & Softening point & $53^{\circ} \mathrm{C}$ & $40-60{ }^{\circ} \mathrm{C}$ & IS : 1205-1978 \\
\hline 3 & Specific Gravity & $1.01 \mathrm{~kg} / \mathrm{m}^{3}$ & Min $0.99 \mathrm{~kg} / \mathrm{m}^{3}$ & IS : 1202:1978 \\
\hline 4 & Ductility & $87 \mathrm{~mm}$ & $\operatorname{Min} 75 \mathrm{~mm}$ & IS : 1208-1978 \\
\hline
\end{tabular}

Table 3

Gradation of Aggregates

\begin{tabular}{|c|c|c|c|c|c|c|c|}
\hline \multirow{2}{*}{ Sieve Size (mm) } & \multicolumn{5}{|c|}{ Percentage Passing of Aggregates } & \multicolumn{2}{c|}{$\begin{array}{c}\text { MORTH Specification } \\
\text { limit }\end{array}$} \\
\cline { 2 - 8 } & $20 \mathrm{~mm}$ & $10 \mathrm{~mm}$ & $\begin{array}{c}\text { Stone } \\
\text { Dust }\end{array}$ & Filler & $\begin{array}{c}\text { Com- } \\
\text { bined }\end{array}$ & Maximum & Minimum \\
\hline 37.5 & 100 & 100 & 100 & 100 & 100 & & 100 \\
\hline 26.5 & 100 & 100 & 100 & 100 & 100 & 100 & 90 \\
\hline 19 & 62 & 100 & 100 & 100 & 89 & 95 & 71 \\
\hline 13.2 & 18 & 96 & 100 & 100 & 74 & 80 & 56 \\
\hline 4.75 & 0 & 54 & 92 & 100 & 52 & 54 & 38 \\
\hline 2.36 & 0 & 14 & 76 & 100 & 33 & 42 & 28 \\
\hline 0.3 & 0 & 5 & 23 & 100 & 14 & 21 & 7 \\
\hline 0.075 & 0 & 2 & 7 & 92 & 7 & 8 & 2 \\
\hline Proportion Percentage & 30 & 35 & 30 & 5 & 100 & & \\
\hline
\end{tabular}

tely the hot Bitumen at $160^{\circ} \mathrm{C}$ is added to the mixture. Similarly in wet process the coarse aggregates and fine aggregate and fly ash were heated to $170^{\circ} \mathrm{C}$. The shredded plastic waste retaining on $2.36 \mathrm{~mm}$ sieve is added in proportion by weight to the hot bitumen which was immediately added to the mixture at $160^{\circ} \mathrm{C}$. In case of combined process certain percentage of waste plastic LDPE, PVC and HDPE was added varying from $6 \%, 8 \%$, and $10 \%$ using dry proc- ess and $4 \%, 6 \%$ and $8 \%$ using wet process to prepare sample of combined process. After proper mixing the mix was placed in the compaction mould and compacted with 75 blows on both face to get Marshall Samples. Three samples were prepared for each proportion and average was calculated. During the experiment PVC type of plastic waste was also used but while spreading the shredded PVC plastic on heated aggregate some gases were coming out 
of the mix and hence PVC plastic was not used for further experiment. Test specimens were

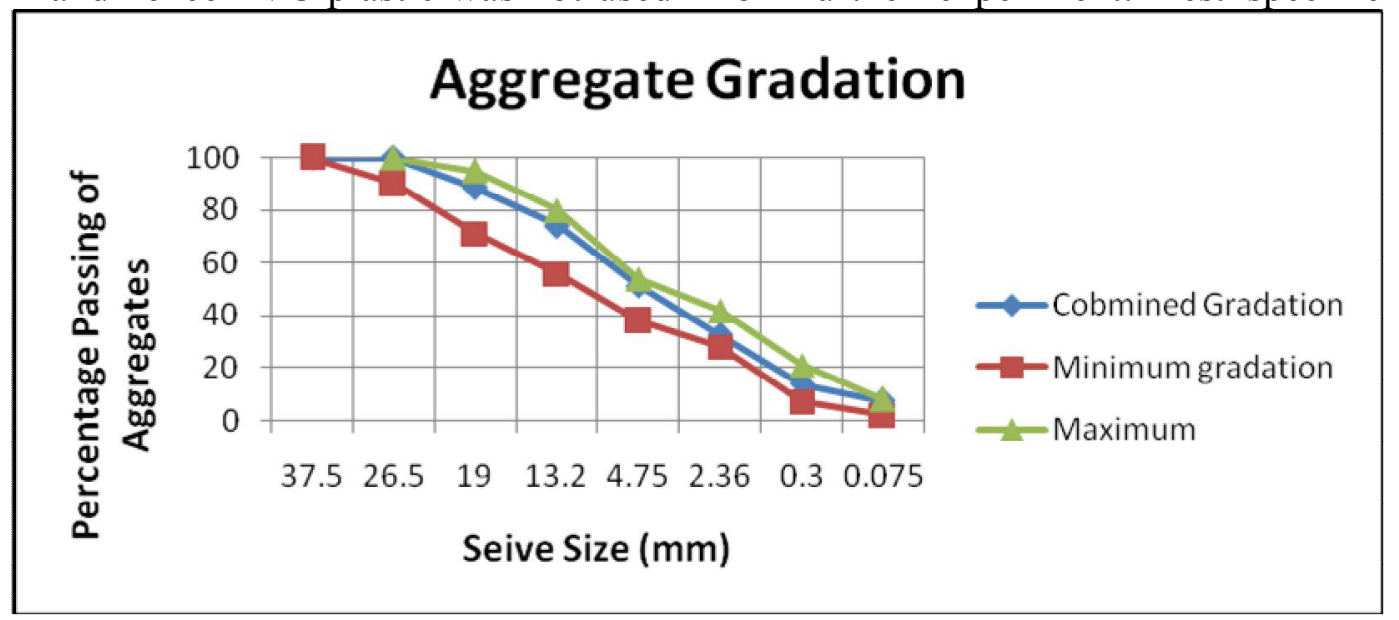

Fig 1. Aggregate Gradation

subjected to axial compression at a uniform vertical deformation rate of $3.2 \mathrm{~mm} / \mathrm{min}$. The compressive strength is determined by dividing the maximum vertical load obtained during deformation at the rate specified by the original cross sectional area of the test specimen (ASTM D 1074-09):

\section{Compressive Strength $=$ Peak Load $/$ Area.}

The compressive strength is reported as the average of three specimens in each case. In order to know the temperature effect on the compressive strength of mixtures, the tests was carried out at two different temperatures $25^{\circ} \mathrm{Cand}$ $60^{\circ} \mathrm{C}$. In order to investigate the effect of water on the compressive strength of mixtures with different additives, the index of retained strength is determined. This value is an indicator of their resistance to moisture susceptibility. The test was conducted at a temperature of $25^{\circ} \mathrm{C}$ i.e unconditioned and the load at which the specimen fails is taken as the dry strength of the bituminous mix. Conditioned specimens are prepared by placing the samples in a water bath maintained at $60^{\circ} \mathrm{C}$ for 24 hours and after that keeping the samples at $25^{\circ} \mathrm{C}$ for two hours. These conditioned specimens are then tested for their strength. The ratio of the compressive strength of the water conditioned specimens to that of dry specimens are taken as the index of retained strength. The indices of retained strength for different mixtures with different type and varying percentage of additives are determined.

\section{Results.}

The variation of the compressive strength with increasing percentage of additive content for the two different temperatures, viz. $25^{\circ} \mathrm{C}$ and $60^{\circ} \mathrm{C}$ for each additive are shown in Table below. All stabilized mixtures shows higher compressive strength than the control mixture. This may be due to the increase in stiffness of the mix. Presence of plastic waste strengthens the bonding between the aggregates provided by the binder and thereby enhancing the stone to stone contact. This will result in increasing the resistance to crushing. It is also observed that the compressive strength decreases with the increase in temperature. But the percentage decrease in strength decreases with the increase in additive content up to a certain level.

It is observed that the compressive strength of sample significantly increases up to $8 \%, 6 \%$ and $12 \%$ for dry process, wet process and combined process respectively for LDPE and HDPE type of waste plastic.

Compressive strength values for unconditioned sample increased by $68.91 \%, 40.37 \%$ and $66.95 \%$ for the mix of $8 \%, 6 \%$ and $12 \%$ LDPE plastic using dry process, wet process and combined process respectively as compared to the compressive strength value of conventional mix. Compressive strength values for conditioned sample increased by $60.45 \%, 40.30 \%$ and $71.94 \%$ for the mix of $8 \%, 6 \%$ and $12 \%$ LDPE plastic using dry process, wet process and com- 
bined process respectively as compared to the compressive strength value of conventional mix.

Similarly Compressive strength values for unconditioned sample increased by $69.79 \%$, $40.71 \%$ and $64.12 \%$ for the mix of $8 \%, 6 \%$ and $12 \%$ HDPE plastic using dry process, wet process and combined process respectively as compared to the Compressive strength value of conventional mix. Compressive strength values for conditioned sample increased by $60.34 \%$, $39.98 \%$ and $70.31 \%$ for the mix of $8 \%, 6 \%$ and $12 \%$ HDPE plastic using dry process, wet process and combined process respectively as compared to the Compressive strength value of conventional mix.

Results for Dry and Wet Process

Table 4

\begin{tabular}{|c|c|c|c|c|c|c|c|c|c|}
\hline \multirow{3}{*}{$\begin{array}{c}\text { Plastic } \\
\text { waste con- } \\
\text { tent } \%\end{array}$} & \multirow{3}{*}{ Plastic Waste } & \multicolumn{4}{|c|}{ Dry Process } & \multicolumn{4}{|c|}{ Wet Process } \\
\hline & & \multicolumn{2}{|c|}{$\begin{array}{l}\text { Peak load } \\
(\mathrm{KN})\end{array}$} & \multicolumn{2}{|c|}{$\begin{array}{c}\text { Maximum } \\
\text { Compressive } \\
\text { strength }(\mathrm{N} / \mathrm{mm} 2) \\
\end{array}$} & \multicolumn{2}{|c|}{$\begin{array}{l}\text { Peak load } \\
(\mathrm{KN})\end{array}$} & \multicolumn{2}{|c|}{$\begin{array}{c}\text { Maximum } \\
\text { Compressive } \\
\text { strength }(\mathrm{N} / \mathrm{mm} 2)\end{array}$} \\
\hline & & $25^{\circ} \mathrm{C}$ & $60^{\circ} \mathrm{C}$ & $25^{\circ} \mathrm{C}$ & $60^{\circ} \mathrm{C}$ & $25^{\circ} \mathrm{C}$ & $60^{\circ} \mathrm{C}$ & $25^{\circ} \mathrm{C}$ & $60^{\circ} \mathrm{C}$ \\
\hline 0 & & 34.10 & 30.77 & 4.2082 & 3.7968 & 34.10 & 30.77 & 4.2082 & 3.7968 \\
\hline 2 & LDPE & 42.33 & 38.30 & 5.2243 & 4.7265 & 34.00 & 30.30 & 4.1959 & 3.7393 \\
\hline 4 & LDPE & 43.63 & 41.10 & 5.3847 & 5.0721 & 38.37 & 35.97 & 4.7347 & 4.4386 \\
\hline 6 & LDPE & 48.00 & 46.10 & 5.9236 & 5.6891 & 47.87 & 43.17 & 5.9071 & 5.3271 \\
\hline 8 & LDPE & 57.60 & 49.37 & 7.1083 & 6.0922 & 46.27 & 42.63 & 5.7097 & 5.2613 \\
\hline 10 & LDPE & 52.50 & 47.67 & 6.4789 & 5.8824 & 43.73 & 39.53 & 5.3970 & 4.8787 \\
\hline 12 & LDPE & 48.30 & 45.47 & 5.9606 & 5.6109 & 38.33 & 34.50 & 4.7306 & 4.2576 \\
\hline 2 & HDPE & 43.93 & 40.77 & 5.4217 & 5.0309 & 34.37 & 33.07 & 4.2411 & 4.0807 \\
\hline 4 & HDPE & 44.33 & 40.90 & 5.4711 & 5.0474 & 38.83 & 35.77 & 4.7923 & 4.4139 \\
\hline 6 & HDPE & 48.53 & 46.23 & 5.9894 & 5.7056 & 47.80 & 43.07 & 5.8989 & 5.3148 \\
\hline 8 & HDPE & 57.90 & 49.33 & 7.1453 & 6.0881 & 43.43 & 42.90 & 5.3600 & 5.2942 \\
\hline 10 & HDPE & 52.77 & 48.67 & 6.5118 & 6.0059 & 43.20 & 38.60 & 5.3312 & 4.7635 \\
\hline 12 & HDPE & 48.17 & 44.57 & 5.9441 & 5.4999 & 38.60 & 34.17 & 4.7635 & 4.2164 \\
\hline
\end{tabular}

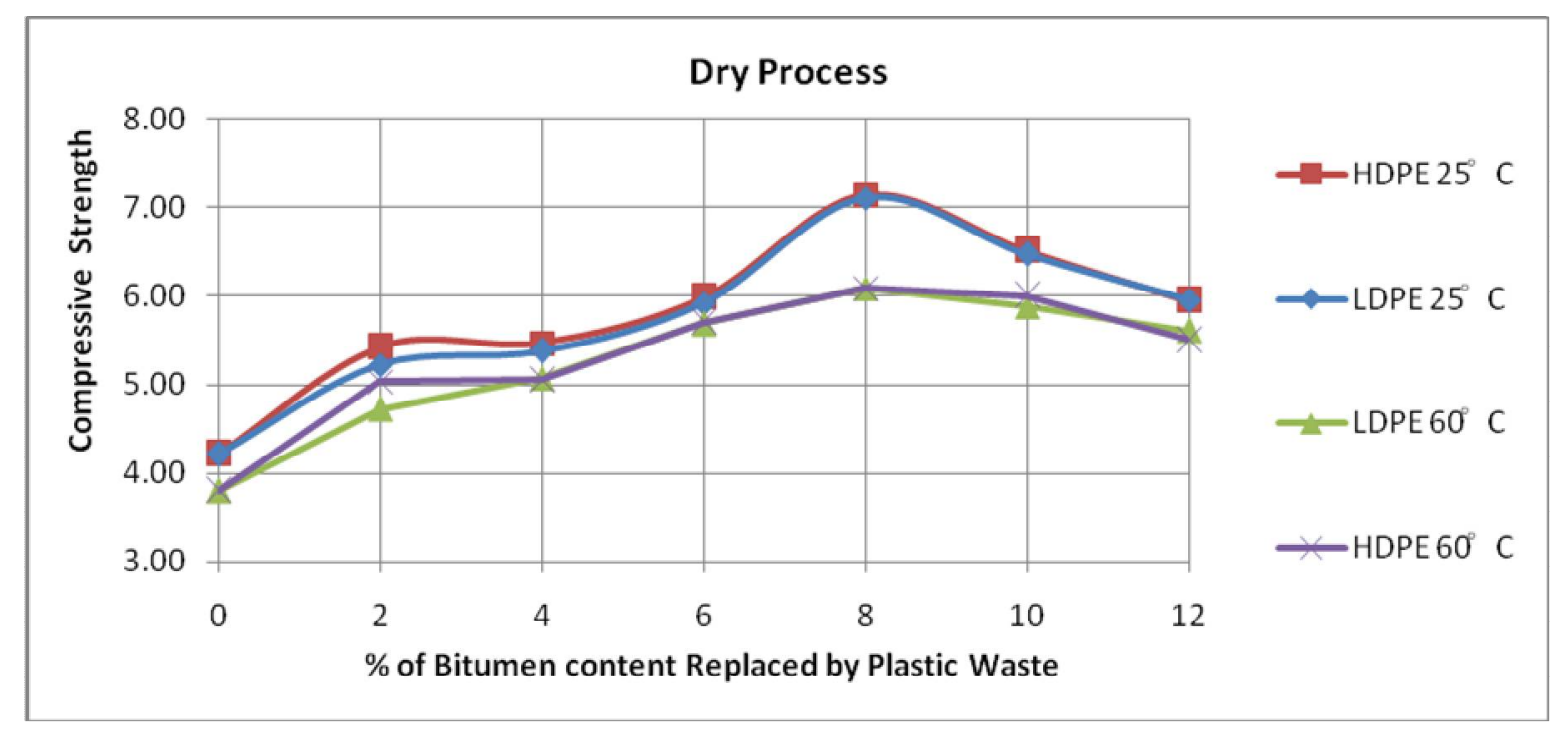

Fig 2. Graph for Dry Process 
Results for Combined Process

\begin{tabular}{|c|c|c|c|c|c|c|}
\hline \multicolumn{7}{|c|}{ Combined Process } \\
\hline & & & \multicolumn{2}{|c|}{ Peak load $(\mathrm{kN})$} & \multicolumn{2}{|c|}{$\begin{array}{l}\text { Maximum Compressive strength } \\
(\mathrm{N} / \mathrm{mm} 2)\end{array}$} \\
\hline $\begin{array}{l}\text { Type of } \\
\text { Plastic } \\
\text { Waste }\end{array}$ & $\begin{array}{l}\text { Dry } \\
\text { Process }\end{array}$ & $\begin{array}{l}\text { Wet } \\
\text { Process }\end{array}$ & $25^{\circ} \mathrm{C}$ & $60^{\circ} \mathrm{C}$ & $25^{\circ} \mathrm{C}$ & $60^{\circ} \mathrm{C}$ \\
\hline & \multicolumn{2}{|c|}{0} & 34.10 & 30.77 & 4.2082 & 3.7968 \\
\hline LDPE & 6 & 4 & 40.20 & 34.77 & 4.9610 & 4.2905 \\
\hline LDPE & 6 & 6 & 47.77 & 43.67 & 5.8948 & 5.3888 \\
\hline LDPE & 8 & 4 & 56.93 & 52.90 & 7.0260 & 6.5283 \\
\hline LDPE & 8 & 6 & 53.97 & 51.83 & 6.6599 & 6.3966 \\
\hline LDPE & 8 & 8 & 50.83 & 47.67 & 6.2732 & 5.8824 \\
\hline LDPE & 10 & 6 & 47.13 & 45.43 & 5.8166 & 5.6068 \\
\hline LDPE & 10 & 8 & 47.13 & 44.10 & 5.8166 & 5.4423 \\
\hline HDPE & 6 & 4 & 41.97 & 41.03 & 5.1790 & 5.0638 \\
\hline HDPE & 6 & 6 & 47.97 & 43.90 & 5.9195 & 5.4176 \\
\hline HDPE & 8 & 4 & 55.97 & 52.40 & 6.9067 & 6.4666 \\
\hline HDPE & 8 & 6 & 53.57 & 51.20 & 6.6105 & 6.3185 \\
\hline HDPE & 8 & 8 & 51.27 & 46.63 & 6.3267 & 5.7549 \\
\hline HDPE & 10 & 6 & 49.03 & 45.40 & 6.0511 & 5.6027 \\
\hline HDPE & 10 & 8 & 47.40 & 44.37 & 5.8495 & 5.4752 \\
\hline
\end{tabular}

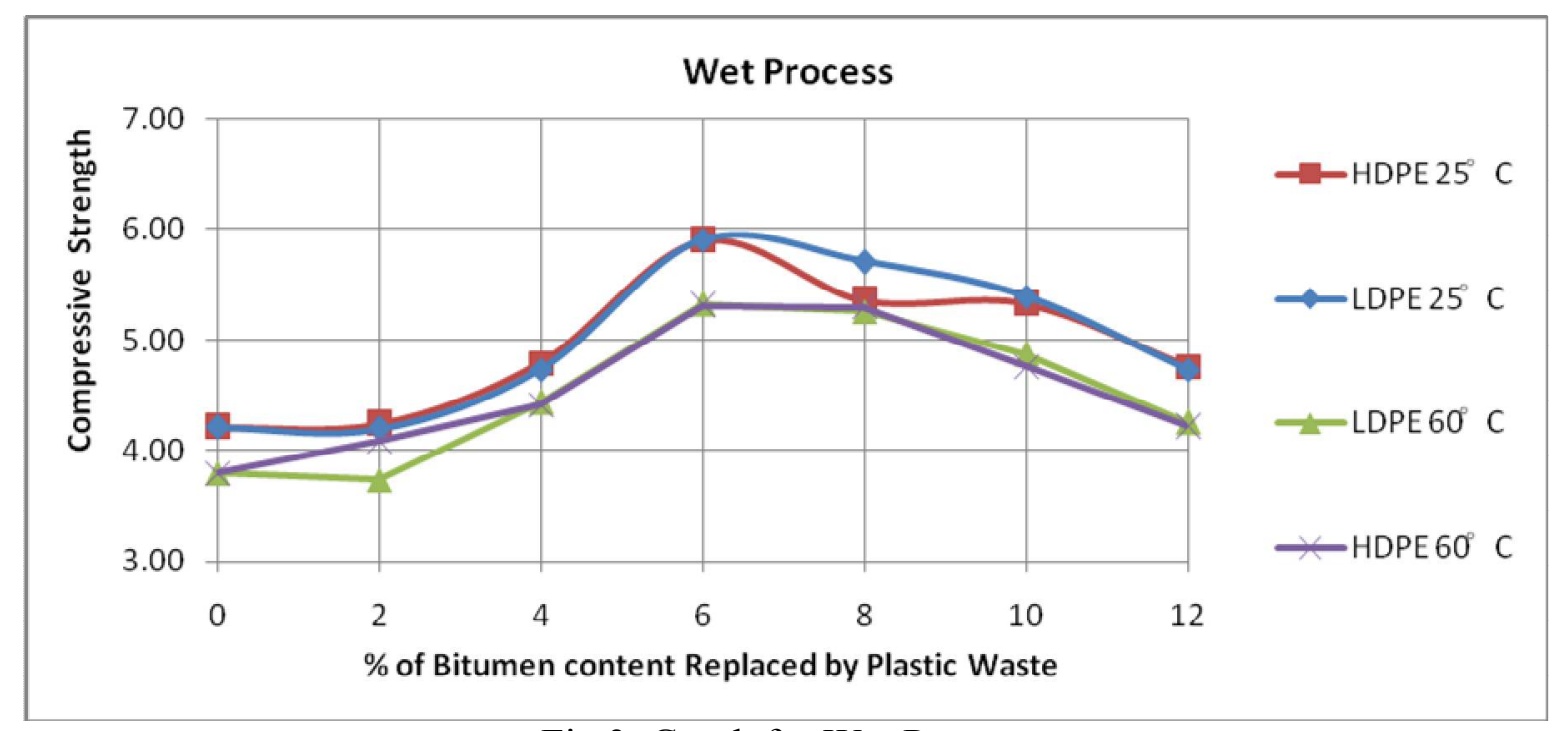

Fig 3. Graph for Wet Process 


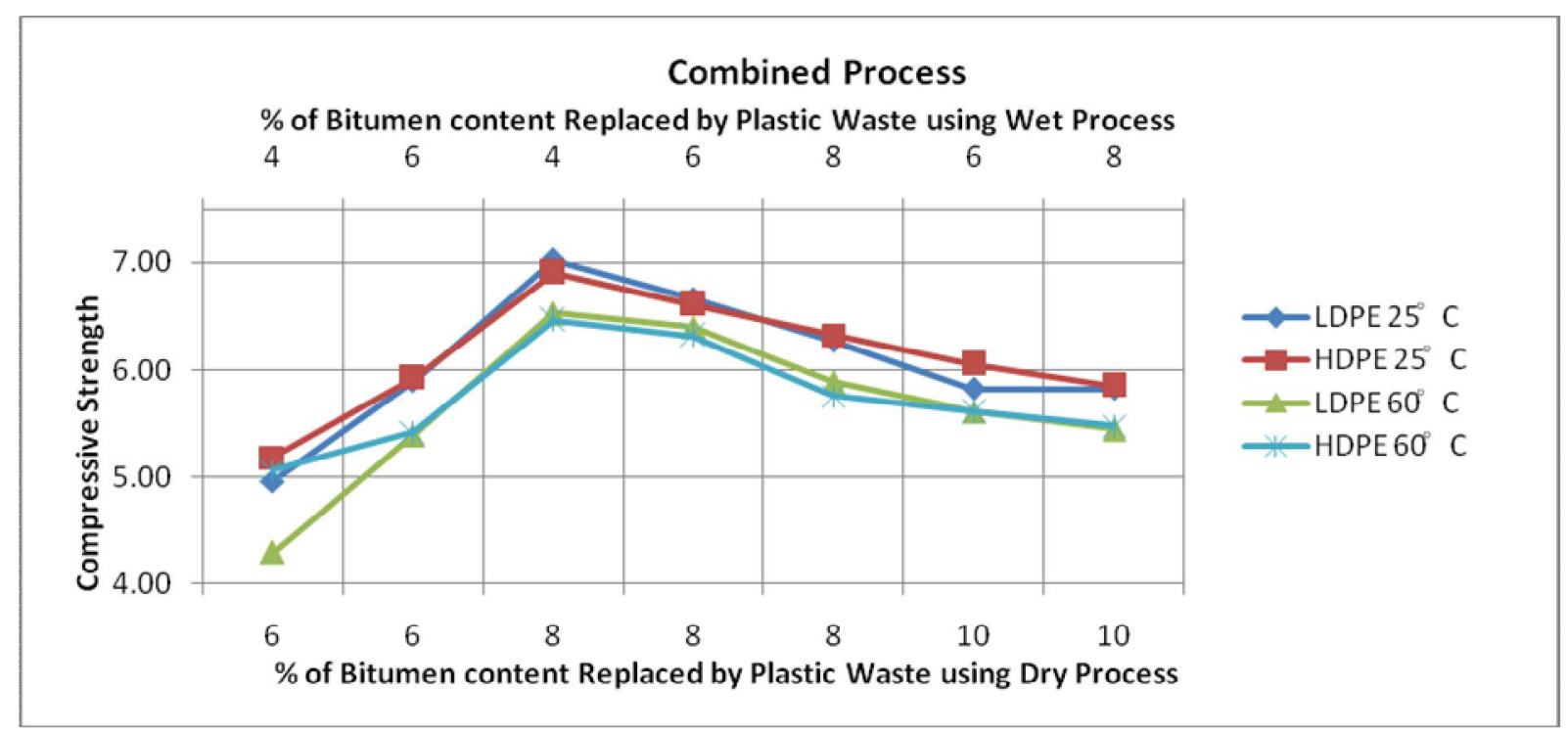

Fig 4. Graph for Combined Process

\section{Conclusion}

- On addition of plastic waste into the mix increase in the compressive strength of bituminous concrete was observed help to increase the load carrying capacity of road pavement.

- The plastic increases the melting point of bitumen hence the bonding between plastic and bitumen increase the overall compressive strength of pavement.

- The heavy loaded vehicles passing through the road due to use of plastic the resistance to crushing dose not effects the roads pavements.

- Due to use of waste plastic the environmental pollution is reduce.

\section{References}

1. Gupta Dr. Y.P., Shailendra Tiwari, Pandey J.K. Utilisation of Plastic Waste in Construction of Bituminous Roads. NBM \& $C W$, 2010, March, p. 92.

2. Bale Amol S. Potential reuse of plastic waste in road construction: a review. International Journal of Advances in Engineering \& Technology (IJAET), 2011, No. 2, pp. 233-236.

3. Bindu C.S., Beena K.S. Waste plastic as a stabilizing additive in Stone Mastic Asphalt. International Journal of Engineering and Technology, 2010, 2.6, pp.379-387.

4. Jassim Hamed M., Omar T. Mahmood, Sheelan A. Ahmed. Optimum use of plastic waste to enhance the Marshall properties and moisture resistance of hot mix asphalt. International Journal Engineering. Trends and Technology, 2014, No. 7, pp. 18-25.

5. Najjar Faris MJ. The Effect of Using Dust of Crushed Boulders on Hma Properties. Kirkuk University Journal for Scientific Studies, 2014, 9.1, pp. 46-58.

6. Tjaronge M.W., Adisasmita S.A., Hustim M. Effect of Buton Granular Asphalt (BGA) on compressive stress-strain behavior of asphalt emulsion mixture. IOP Conference Series: Materials Science and Engineering, 2017, Vol. 271, No. 1.

7. Bindu C.S., Beena K.S. Influence of additives on the charactaristics of stone matrix asphalt (Doctoral dissertation, Cochin University of Science and Technology). 2012.

8. Agrawal H.S., Dr. Borkar R.P. Utilization of plastic waste in construction of pavement. International Journal of Innovative Research in Science and Engineering, 2017, No.3, Issue 03.

9. Tuncan Mustafa, Ahmet Tuncan, Altan Cetin. The use of waste materials in asphalt concrete mixtures. Waste Management \& Research, 2003, 21.2, pp. 83-92.

10. Gaus Abdul, et al. Compressive strength of asphalt concrete binder course (AC-BC) mixture using buton granular asphalt (BGA). Procedia Engineering, 2015, 125, pp. 657-662.

11. Tiwari Anurag V., Rao Y.R.M. Study of Plastic Waste Bituminous Concrete Using Dry 
Process of Mixing for Road Construction. Transport \& Logistics, 2017, pp. 17-43.

12. Tiwari Anurag V., Rao Y.R.M. Investigation on Utility of Plastic Waste as an Additive for Bituminous Concrete Using Wet Process of Mixing. Science and Transport Progress. Bulletin of Dnipropetrovsk National University of Railway Transport, 2017, 6 (72), pp. 83-92.

13. IS 2386 (Part I) - 1963 Indian Standard. Methods of Test For Aggregates for Concrete Part I Particle Size And Shape.

14. IS 2386-3 - 1963 Methods Of Test For Aggregates For Concrete - Part III Specific Gravity, Density, Voids, Absorption And Bulking.

15. IS 2386 (Part IV) - 1963 Indian Standard. Methods of Test for Aggregates for Concrete. Part IV Mechanical Properties.
16. IS 1203: 1978 Methods of testing tar and bituminous material - Determination of penetration.

17. IS 1205: 1978 Methods for testing tar and bituminous materials - Determination of Softening point.

18. IS 1202: 1978 Methods of testing tar and bituminous materials - Determination of specific gravity.

19. IS 1208: 1978 Methods of testing tar and bituminous material - Determination of ductility.

20. ASTM D 6931 (2007), Indirect Tensile (IDT) Strength for Bituminous Mixtures, American Society for Testing and Materials, Philadelphia. 